\title{
Pensonomonoor
}

2015, vol. 73, 33-45

http://dx.doi.org/10.12657/denbio.073.004

\author{
Zdeněk Vacek, Stanislav Vacek, Lukáš Bílek, Jiři Remeš, \\ Igor Štefanč́k
}

\section{Changes in horizontal structure of natural beech forests on an altitudinal gradient in the Sudetes}

\author{
Received: 13 December 2013; Accepted: 25 September 2014
}

\begin{abstract}
The article describes horizontal structure of the tree layer, natural regeneration, snags and crown projections of natural beech stands on three permanent research plots in the wide altitudinal range in the Krkonoše Mts (Czech Republic). The spatial structure was classified from 1980 to 2010 and subsequently the prediction of spontaneous development with an outlook for 30 years (to 2040) was done by growth simulator. Hopkins-Skellam index, Pielou-Mountford index, Clark-Evans index and Ripley's K-function were calculated. Further, the vertical structure and total diversity index was evaluated. The horizontal structure of individuals in the tree layer had not changed significantly during the monitored years. Tree spatial pattern of the lowest altitude lying herb-rich beech forest was mostly regular to random, in acidophilous mountain beech forest predominantly random and in fragments of beech groups around the timberline aggregated. Juvenile growth on all investigated plots was distributed aggregated and snags randomly. The horizontal structure of crown projection centroids had always higher values toward the regularity than tree layer and was random to regular. The result of principal component analysis also confirmed that spatial pattern was dependent on the altitude, but also on the number of trees.
\end{abstract}

Additional key words: European beech (Fagus sylvatica L.), spatial pattern, structural indices, forest dynamics, development prediction

Addresses: Z. Vacek, S. Vacek, L. Bilek, J. Remeš, I. Štefančík, Czech University of Life Sciences, Prague, Faculty of Forestry and Wood Sciences, Kamýcká 129, 16521 Prague, Czech Republic, e-mail: vacekz@fld.czu.cz

I. Štefančík, National Forest Centre, T.G. Masaryka 22, 46001 Zvolén, Slovak Republic

\section{Introduction}

Modifications of spatial patterns of important forest attributes such as living mature trees and their crowns, deadwood and natural regeneration along altitudinal gradient may result from various environmental conditions such as climate, edaphic conditions, disturbance regime and human impact.
Surprisingly these aspects have been studied along extensive altitudinal gradients worldwide (Barrera et al. 2000; Motta et al. 2006; Holeksa et. al. 2007; Girardin et al. 2014), but less information has been gathered from temperate zone with special focus on beech dominated forests.

Due to its ecological plasticity and broad ecological amplitude European beech (Fagus sylvatica L.) occurs 
over a wide range of mesic soils, with $\mathrm{pH}$ ranging from 3.5 to over 7.0, and humus form mull to mor with the exception of pseudogleys, or soils with reducing conditions within $20 \mathrm{~cm}$ from the soil surface (Le Tacon 1981; Otto 1994). In central Europe beech dominates the major and central part of the moisture and nutrient range of forests and is absent only where rain is insufficient, or where the soil is too dry (Ellenberg 1996). In the conditions of the Czech Republic, beech occurred originally in the submontane, montane and subalpine zones from $300 \mathrm{~m}$ a.s.l. to $1300 \mathrm{~m}$ a.s.l. (Neuhäuslová et al. 1998), but was on most sites replaced by Norway spruce (Picea abies /L./ Karst) as economically more interesting species. In the present Czech Republic, the representation of beech has been reduced from more than $40 \%$ of the natural representation to less than $8 \%$ today (Ministry of Agriculture of the Czech Republic 2013) and most beech forest have been modified in their tree species composition and structure.

In Central European conditions extensive remnants of old-growth beech forests remain to a larger extent in the Carpathians, but in the absence of strong human impact valuable examples of natural or near-natural beech stands are also known from the Central European middle-mountains including also the mountain range of the Sudetes (Jeník 1998). Man-made forest stands mostly have lower volumes of dead wood (standing and fallen) - (Christensen et al. 2005), simplified DBH and age structure and regular distribution of trees, while natural forest stands that originate from natural regeneration (from seeds, vegetative sprouts or by layering) usually have an aggregated or randomly irregular initial distribution (Vacek et al. 2010a, 2010b) and generally higher structural heterogeneity (Rademacher et al. 2001; Rozas 2006). In the course of stand development this type of distribution changes toward moderately regular distribution in favourable environmental conditions (Korpel 1995; Wolf 2005), while in less favourable conditions more irregular or aggregated structures are expected (Vacek et al. 2010b).

Commonly, structural indices and functions are used to study the structure of forest stands. In numerous studies on horizontal structure of forest stands, distribution indices based on a distance of trees to the nearest neighbour have frequently been used for a long time. Probably the best-known aggregation index R (Clark and Evans 1954) compares the actual distance of a tree to its nearest neighbour with a distance fulfilling the condition of purely random stand structure given by the Poisson probability distribution. Frequently are also used distribution indices based on a distance between a randomly selected point and actual positions of trees. The first index of this type was proposed by Hopkins and Skellam (1954); it is based on the principle that the population has a random distribution in case that the distribution of distances from any point to its nearest neighbour coincides with the distribution of distances from a randomly selected tree to its nearest neighbour. The same principle was applied e.g. by Mountford (1961).

In the seventies of the $20^{\text {th }}$ century the first distribution functions were proposed (Geyer 1999) with the objective to express the horizontal structure in a continuous way. Their advantage is that they document the intensity of particular types of distribution to various distances (Pretzsch 2009). The frequently used $K$-function (Ripley 1977) shows the mean value of the number of individuals situated at a distance smaller than or equal to $r$ from a randomly chosen individual.

Conversly, a relatively small number of authors have dealt with indices describing the vertical structure (Ferris-Kaan et al. 1998; Weber 1999). The Arten-profil index (Pretzsch 1992) is based on combinations of the Shannon index of species diversity divided into three storeys. Neumann and Starlinger (2001) proposed the vertical evenness index based on tree distribution into four stand layers closely related to their crown projections.

To evaluate the overall diversity of forest stand by means of complexity indices is more suitable than the above-mentioned structural indices aimed at one component of the stand structure only. Complexity index (Holdridge 1967) is calculated as the product of dominant height, basal area, tree number and species number, but data on tree distribution are missing in this index (Neumann and Starlinger 2001). The stand diversity index (Jaehne and Dohrenbusch 1997) is based on the combination of species composition, vertical and horizontal structure and crown differentiation. An extensive overview of indices concerning stand structure diversity is shown for instance in the work of McElhinny et al. (2005).

In the National park of the Krkonoše Mts. the near-natural management increasingly makes use of natural processes in forest stands, especially of natural regeneration, either spontaneous or controlled (Kooijman et al. 2000). However, such approach requires deep knowledge of the structure and development of near-natural forest stands in the particular forest stand types. Hence, structural characteristics of autochthonous beech stands at different altitudes may be an important source of knowledge for forest managers and conservationists.

The object of this paper was to evaluate forest structure with different habitat and stand characteristics on three permanent research plots (PRP) representing fragments of autochthonous stands in herbrich beech forests, acidophilous beech forests and in beech groups around the timberline in the eastern Krkonoše Mts. including prediction of their develop- 
ment by 2040. The aim of our study was to demonstrate the impact of altitude (climatic and edaphic habitat conditions) on the horizontal structure of beech stands in the optimum to the initial break up stage left to be regulated by natural processes.

\section{Materials and Methods}

\section{Site descriptions}

The study was conducted on three permanent research plots (PRP) situated in the $1^{\text {st }}$ zone of the eastern part of the Krkonoše National Park, Czech Republic. The National Park is covering area of 550 $\mathrm{km}^{2}$ and is located on the Czech-Polish border, in Krkonoše Mts. The parent rock is formed mainly by granite, mica schist and phyllite. At the lowest altitudes Cambisols are dominant and above 1,000 m Podzols prevail. Average annual precipitation varies with altitude and aspect from $860 \mathrm{~mm}$ to $1260 \mathrm{~mm}$, mean annual temperature decreases with altitude from $6.1^{\circ} \mathrm{C}$ to $2.6^{\circ} \mathrm{C}$.

PRPs were established on given sites in order to cover wide altitude range of European beech ( $F a-$ gus sylvatica L.) in this locality from herb-rich beech forests (PRP 31) to acidophilous mountain beech forests (PRP 29) and beech forests under the pronounced summit phenomenon (PRP 27). PRPs were established in 1980 and they are $50 \times 50 \mathrm{~m}$ in size, i.e. 0.25 ha. Fig. 1 shows the localization of PRPs and Table 1 shows the basic characteristics of particular forest stands.

Table 1. Overview of basic characteristics of particular forest stands (according to forest management plan, stand 2014)

\begin{tabular}{|c|c|c|c|c|c|c|c|c|c|c|c|c|}
\hline & Plot name & GPS & $\begin{array}{c}\text { Tree } \\
\text { species }\end{array}$ & Age & $\begin{array}{l}\text { Height } \\
\text { (m) }\end{array}$ & $\begin{array}{l}\mathrm{DBH} \\
(\mathrm{cm})\end{array}$ & $\begin{array}{l}\text { Volume } \\
\left(\mathrm{m}^{3} \cdot \mathrm{ha}^{-1}\right)\end{array}$ & $\begin{array}{l}\text { Altitude } \\
\text { (m) }\end{array}$ & $\begin{array}{l}\text { Expo- } \\
\text { sure }\end{array}$ & $\begin{array}{c}\text { Gradient } \\
\left({ }^{\circ}\right)\end{array}$ & $\begin{array}{l}\text { For- } \\
\text { est } \\
\text { type }\end{array}$ & $\begin{array}{l}\text { Air pollut. } \\
\text { zone }\end{array}$ \\
\hline 31 & $\begin{array}{l}\text { U Hadí } \\
\text { cesty F }\end{array}$ & $\begin{array}{l}50^{\circ} 40^{\prime} 02^{\prime \prime} \mathrm{N} \\
15^{\circ} 53^{\prime} 02^{\prime \prime} \mathrm{E}\end{array}$ & $\begin{array}{l}\text { beech } \\
\text { maple } \\
\text { spruce }\end{array}$ & $\begin{array}{c}157 / \\
15\end{array}$ & $\begin{array}{l}30 \\
28 \\
32\end{array}$ & $\begin{array}{l}44 \\
40 \\
42\end{array}$ & $\begin{array}{r}407 \\
42 \\
21\end{array}$ & 740 & NE & 23 & $6 \mathrm{~B} 9$ & $\mathrm{D}$ \\
\hline 29 & $\begin{array}{l}\text { U Bukového } \\
\text { pralesa B }\end{array}$ & $\begin{array}{l}50^{\circ} 38^{\prime} 44^{\prime \prime} \mathrm{N} \\
15^{\circ} 52^{\prime} 14^{\prime \prime} \mathrm{E}\end{array}$ & $\begin{array}{l}\text { beech } \\
\text { spruce }\end{array}$ & $\begin{array}{c}174 / \\
24 / 10\end{array}$ & $\begin{array}{l}26 \\
29\end{array}$ & $\begin{array}{l}48 \\
47\end{array}$ & $\begin{array}{r}212 \\
24\end{array}$ & 950 & SE & 16 & $6 \mathrm{~S} 1$ & C \\
\hline 27 & $\begin{array}{c}\text { U Bukového } \\
\text { pralesa A }\end{array}$ & $\begin{array}{l}50^{\circ} 38^{\prime} 57^{\prime \prime} \mathrm{N} \\
15^{\circ} 51^{\prime} 46^{\prime \prime} \mathrm{E}\end{array}$ & $\begin{array}{l}\text { beech } \\
\text { spruce } \\
\text { rowan }\end{array}$ & $\begin{array}{c}174 / \\
31 / 18\end{array}$ & $\begin{array}{l}15 \\
19 \\
15\end{array}$ & $\begin{array}{l}31 \\
34 \\
22\end{array}$ & $\begin{array}{r}85 \\
45 \\
2\end{array}$ & 1030 & SW & 3 & $6 Z 0$ & $\mathrm{C}$ \\
\hline
\end{tabular}

Explanatory notes: Age - age of trees in particular tree layers; $6 \mathrm{ZO}$ - dwarf spruce-beech forest growing on the ridge, $6 \mathrm{~S} 1$ - acid sprucebeech forest with broad buckler fern, $6 B 9$ - rich spruce-beech forest growing on the slope; air pollution threat zones $C-2-5 \%$ of trees die per year, $D-0-2 \%$ of trees die per year.

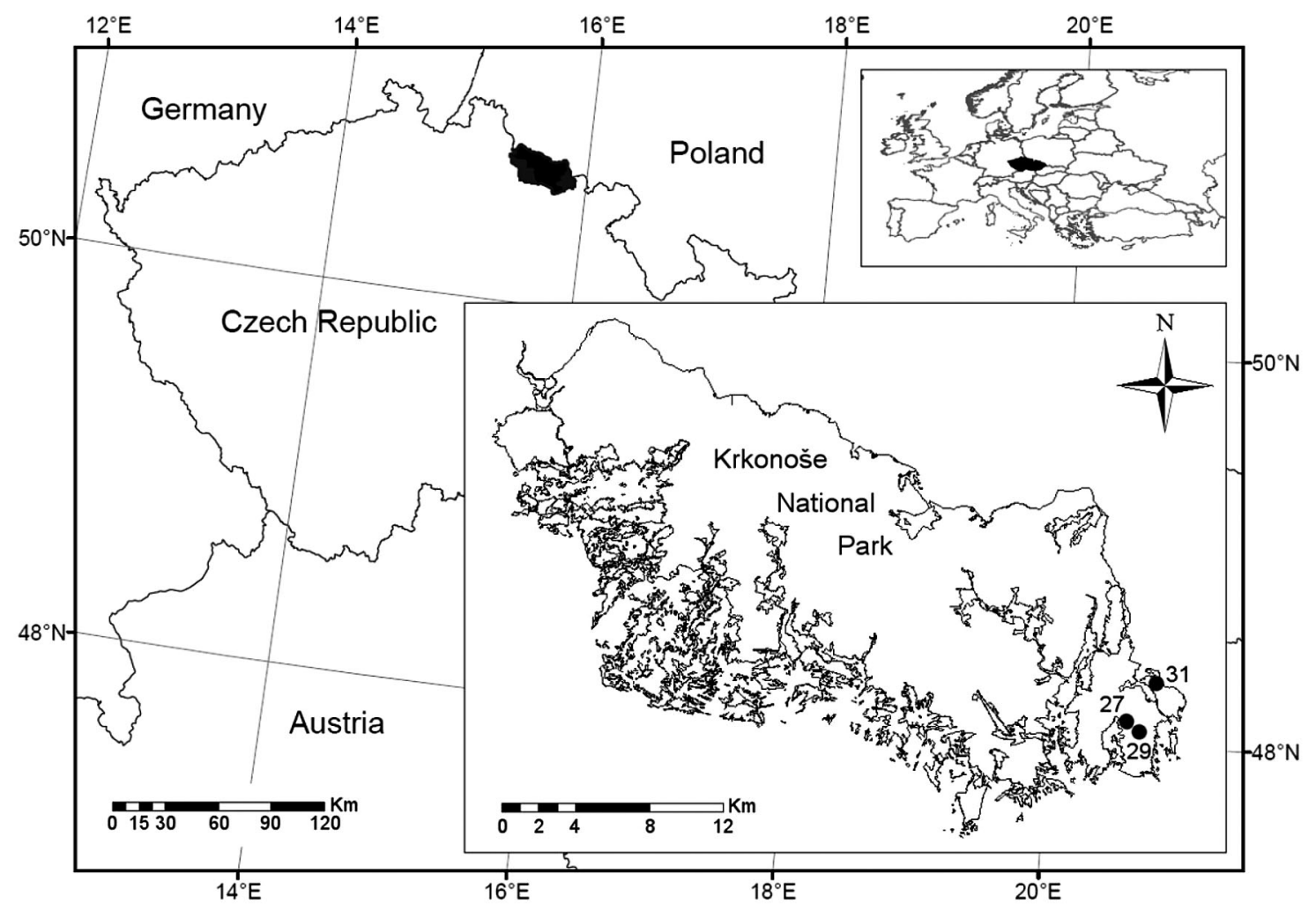

Fig. 1. Localization of permanent research plots in the Krkonoše National Park 
On the lowest-lying PRP 31 the upper storey is entirely composed of beech. Mean height of the stand is $24.4 \mathrm{~m}$ (top height $29.0 \mathrm{~m}-95 \%$ quantile of tree heights), mean breast-height diameter $\left(\mathrm{DBH}_{1.3}\right)$ is $41.2 \mathrm{~cm} \pm 10.4$ S.D. and stocking 7 . The soil type is modal Cambisol. In 2014 the standing volume amounted to $394 \mathrm{~m}^{3} \cdot \mathrm{ha}^{-1}$, total current increment was $6.5 \mathrm{~m}^{3} \cdot$ ha $^{-1}$.year ${ }^{-1}$ and total mean increment was $2.26 \mathrm{~m}^{3} \cdot \mathrm{ha}^{-1}$.year ${ }^{-1}$. On PRP 29 the upper storey is dominated by beech $(97 \%)$ with admixture of spruce (3\%). Mean height of the stand is $11.9 \mathrm{~m}$ (top height $26.5 \mathrm{~m}$ ), mean $\mathrm{DBH}_{1.3} 26.4 \mathrm{~cm} \pm 19.5$ S.D. and stocking 8. The soil type is modal Cambisol. In 2014 the standing volume amounted to $436 \mathrm{~m}^{3} \cdot \mathrm{ha}^{-1}$, total current increment was $4.9 \mathrm{~m}^{3} \cdot$ ha $^{-1}$.year ${ }^{-1}$ and total mean increment was $2.09 \mathrm{~m}^{3}$. $\mathrm{ha}^{-1}$.year ${ }^{-1}$. On the highest altitude lying PRP 27 the upper storey is dominated by beech $(96 \%)$ with admixture of rowan Sorbus aucuparia L. (3\%) and spruce (1\%). Mean height of the stand is $11.2 \mathrm{~m}$ (top height $14.6 \mathrm{~m}$ ), mean $\mathrm{DBH}_{1.3} 26.2 \mathrm{~cm}$ \pm 7.5 S.D. and stocking 6 . The soil type is modal Cryptopodzol. In 2010 the standing wood volume amounted to $218 \mathrm{~m}^{3} \cdot \mathrm{ha}^{-1}$, total current increment was $3.8 \mathrm{~m}^{3} \cdot$ ha $^{-1}$.year ${ }^{-1}$ and total mean increment was $1.12 \mathrm{~m}^{3} \cdot$ ha $^{-1} \cdot$ year $^{-1}$.

\section{Data collection}

To determine the structure and especially position of all trees, natural regeneration and snags on PRPs was recorded using the FieldMap technology and equipment (IFER-Monitoring and Mapping Solutions Ltd.). The measurement of tree layer comprised all individuals whose breast-height diameter over bark was $\mathrm{DBH}_{1.3} \geq 4 \mathrm{~cm}$. These secondary characteristics were also measured in trees: $\mathrm{DBH}_{1.3}$, height of the tree, height of the green crown setting with a hypsometer Laser Vertex and crown projection at least at 4 points along the crown perimeter. All measurements of tree layer were repeated every fifth year from 1980 to 2010 (with the exception of the first 10-year period) with standard dendrometric methodology (Šmelko 2007). On each PRP one transect of $50 \times 5 \mathrm{~m}$ in size $\left(250 \mathrm{~m}^{2}\right)$ was established for the study of horizontal structure of natural regeneration (seedling from $10 \mathrm{~cm}$ height to saplings with $\left.\mathrm{DBH}_{1.3}<4 \mathrm{~cm}\right)$. The transect was outlined so that it would represent the average frequency and maturity of advance growth on the entire PRP.

\section{Data analysis}

Horizontal structure was evaluated on the particular plots separately for natural regeneration and for the tree layer. Hopkins-Skellam index (Hopkins and Skellam 1954), Pielou-Mountford index (Mountford 1961), Clark-Evans index (Clark and Evans 1954)
Table 2. Overview of indices describing the horizontal structure and their common interpretation

\begin{tabular}{lccc}
\hline \multicolumn{1}{c}{ Index } & Mean value & Aggregation & Regularity \\
\hline Hopkins-Skellam & $\mathrm{A}=0.5$ & $\mathrm{~A}>0.5$ & $\mathrm{~A}<0.5$ \\
Pielou-Mountford & $\alpha=1$ & $\alpha>1$ & $\alpha<1$ \\
Clark-Evans & $\mathrm{R}=1$ & $\mathrm{R}<1$ & $\mathrm{R}>1$ \\
\hline
\end{tabular}

and Ripley's K-function (Ripley 1977) were calculated. The horizontal structure of the tree layer is related to the years 1980, 2010 and 2040, that of natural regeneration to 2010 , snags and crown projection to 1980 and 2010. The criteria of structural indices are given in Table 2. For a completely random distribution of points $K(r)=\varpi \mathrm{r}^{2}$ is applicable. In case that the value $K(r)$ calculated from real data is higher than the expected value, it can be explained as a trend of forming point clusters at a distance $r$. Inversely, the lower $K(r)$ value indicates a trend of repulsion, i.e. the formation of regular point structures.

To calculate these characteristics describing the horizontal structure across the plot the PointPro 2.1 program (Copyright 2010 Daniel Zahradnik) was used. The test of the significance $(\alpha=0.05)$ of deviations from the values expected for random distribution of points was performed by Monte Carlo simulation. The mean values of $K$-function were estimated as arithmetic means from $K$-functions computed for 1999 randomly generated point structures. In the results statistically significant values (exceeding the confidence interval) are designated with asterisk.

The prediction of the horizontal structure of the tree layer with an outlook of 30 years, using the simulation of spontaneous development and assuming the ecologically stable environment, was done by means of the SIBYLA growth simulator of forest biodynamics (Fabrika 2005). Individual tree data including their age and coordinates were used as source data. Soil moisture and nutrients were derived from the typological classification system. Climatic information was obtained from a nearby meteorological station at Rýchory. For a higher statistical significance of prediction the $36 \times$ repetition of simulation was used $(6 \times$ repetition of structure generation, $6 \times$ repetition of prognosis) - (Špulák and Souček 2010). The arithmetic mean of variables from repeated simulations was calculated from the resultant value and then the simulation most approaching the mean was chosen. Stand diversity was evaluated by the following indices: Arten-profil index (Pretzsch 1992), diameter and height differentiation index (Füldner 1995), where the values range is between $0-1$, when 0 represents minimum and 1 the maximum one and total diversity index (Jaehne and Dohrenbusch 1997), where values $\mathrm{B} \geq 9$ indicate rich structure, and the index value below 4 indicates a monotonous stand structure. Next, crown projection area and crown closure 
(canopy overlying the forest floor) was derived and stand density index (SDI) was calculated as measure of stand density (Crookston and Stage 1999). Situational maps were made in ArcGIS program (Copyright 1995-2010 Esri).

Unconstrained principal component analysis (PCA) in Canoco for Windows 4.5 program (ter Braak and Šmilauer 2002) was used to analyze relationships among basic mensurational characteristic, slope of terrain, altitude, age of stand, time and all structural diversity with emphasis on horizontal structure in order to reveal similarity of all records. Data were log-transformed, centered and normed before the analysis. The results of the PCA analysis were visualized in the form of an ordination diagram constructed by CanoDraw program.

\section{Results}

\section{PRP 31}

Almost the entire plot of the autochthonous beech stand has a two-storey structure while single trees of the middle storey occur only locally and sparsely. The tree layer is composed only of beech with 236 trees.ha $^{-1}$ (SDI 0.50). Fig. 2 shows the horizontal structure of this stand in 2010. The total per-hectare crown projection area is 2.06 ha at present and
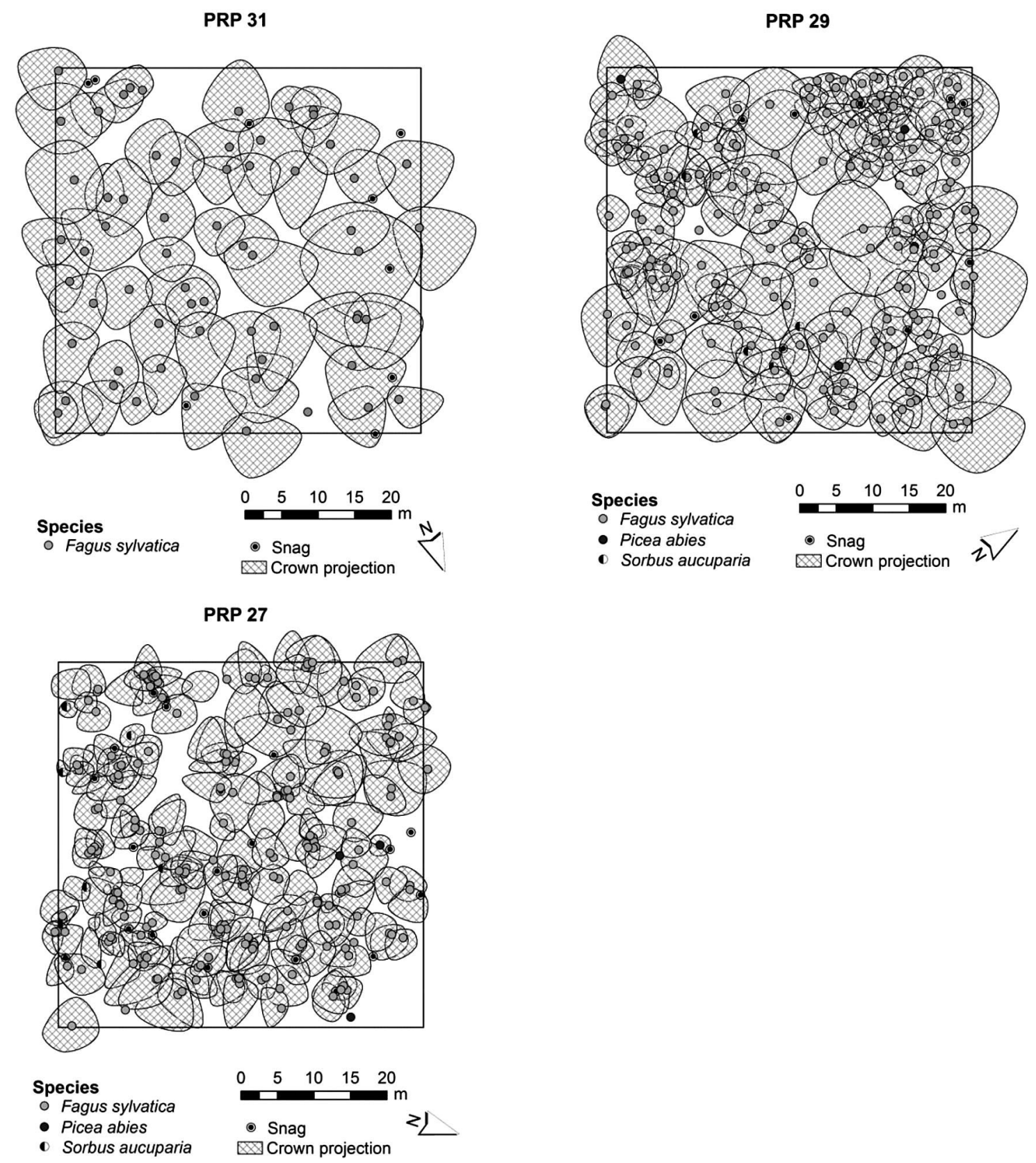

Fig. 2. Horizontal structure of the tree layer of the beech forest on PRP 31, 29 and 27 
Table 3. Indices describing the horizontal structure of tree layer, natural regeneration, crown projection and snags on PRPs

\begin{tabular}{cccccccccc}
\hline Index & PRP & $\begin{array}{c}\text { Tree layer } \\
1980\end{array}$ & $\begin{array}{c}\text { Tree layer } \\
2010\end{array}$ & $\begin{array}{c}\text { Tree layer } \\
2040\end{array}$ & $\begin{array}{c}\text { Regenera- } \\
\text { tion 2010 }\end{array}$ & $\begin{array}{c}\text { Crown p. } \\
1980\end{array}$ & $\begin{array}{c}\text { Crown p. } \\
2010\end{array}$ & Snags 1980 & Snags 2010 \\
\hline \multirow{2}{*}{$\mathrm{A}$} & 31 & $0.367^{*}$ & $0.319^{*}$ & $0.285^{*}$ & $0.688^{*}$ & $0.293^{*}$ & $0.313^{*}$ & 0.408 & 0.463 \\
$\mathrm{H} \& \mathrm{Si}$ & 29 & 0.450 & 0.533 & 0.493 & $0.640^{*}$ & 0.499 & 0.449 & 0.543 & 0.570 \\
& 27 & $0.705^{*}$ & $0.724^{*}$ & $0.685^{*}$ & $0.722^{*}$ & $0.485^{*}$ & 0.462 & 0.654 & 0.451 \\
\hline \multirow{2}{*}{$\alpha$} & 31 & 0.881 & $0.737^{*}$ & $0.711^{*}$ & $2.102^{*}$ & $0.682^{*}$ & $0.721^{*}$ & 1.093 & 1.214 \\
$\mathrm{P} \& \mathrm{Mi}$ & 29 & 1.014 & 1.129 & 1.096 & $1.670^{*}$ & 1.220 & 1.021 & 1.216 & 1.329 \\
& 27 & $1.722^{*}$ & $1.654^{*}$ & $1.636^{*}$ & $2.676^{*}$ & 1.119 & 1.019 & 1.911 & 1.073 \\
\hline \multirow{2}{*}{$\mathrm{R}$} & 31 & $1.267^{*}$ & $1.276^{*}$ & $1.383^{*}$ & $0.892^{*}$ & $1.373^{*}$ & $1.352^{*}$ & 1.275 & 1.250 \\
$\mathrm{C} \& \mathrm{Ei}$ & 29 & 1.115 & 0.996 & 1.054 & $0.840^{*}$ & 0.982 & $1.141^{*}$ & 1.113 & 1.092 \\
& 27 & $0.746^{*}$ & $0.647^{*}$ & $0.724^{*}$ & $0.788^{*}$ & 1.041 & $1.122^{*}$ & 0.881 & 1.154 \\
\hline
\end{tabular}

* Statistically significant

crown closure is 0.87 . Neither of these two values has almost changed over 30 years of study. The total per hectare number of natural regeneration recruits is 73 800: beech accounts for $68 \%$, sycamore maple Acer pseudoplatanus L. for $22 \%$ and rowan for $9 \%$ whereas the representation of the other species (Norway spruce, European ash /Fraxinus excelsior L./ and red elderberry /Sambucus racemosa L./) is below $1 \%$. As a result of the relatively slow and irregular opening-up of canopy height and diameter differenti-

TREE LAYER 1980

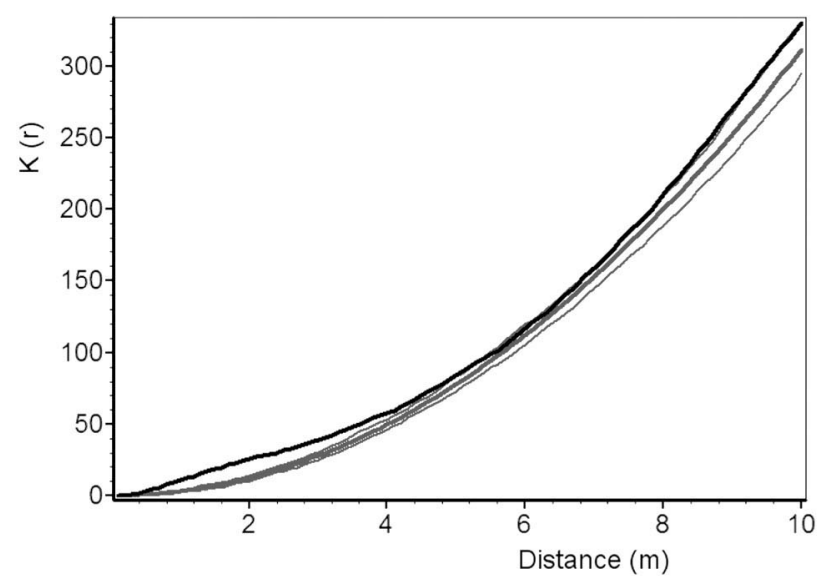

TREE LAYER 2040

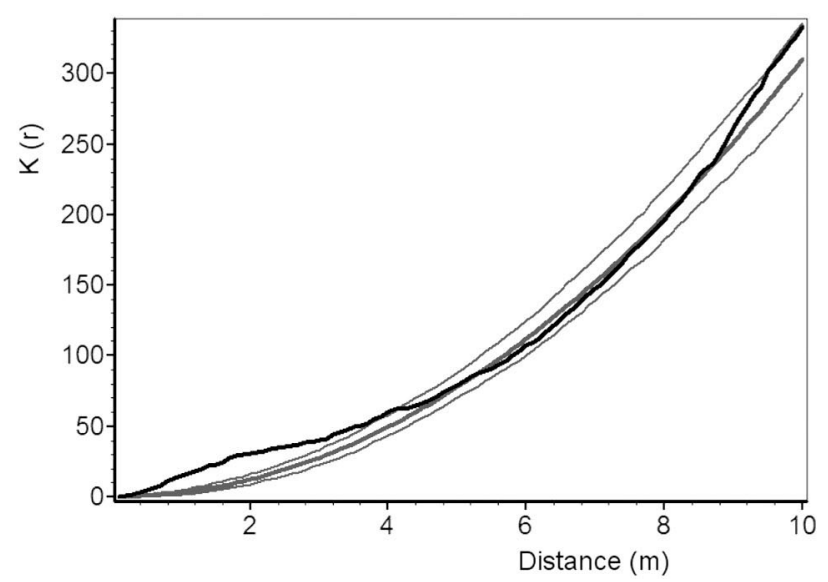

ated natural regeneration is gradually formed there. Crown projection area and crown closure of natural regeneration are 0.12 and 0.10 ha, respectively. Beech, European ash and sycamore maple regeneration is mostly concentrated into biogroups. The other tree species are mostly interspersed as single trees but are also in clumps.

Table 3 documents index values of the horizontal structure of individuals of the tree layer. According to all three calculated structural indices (Hopkins-Skel-

TREE LAYER 2010

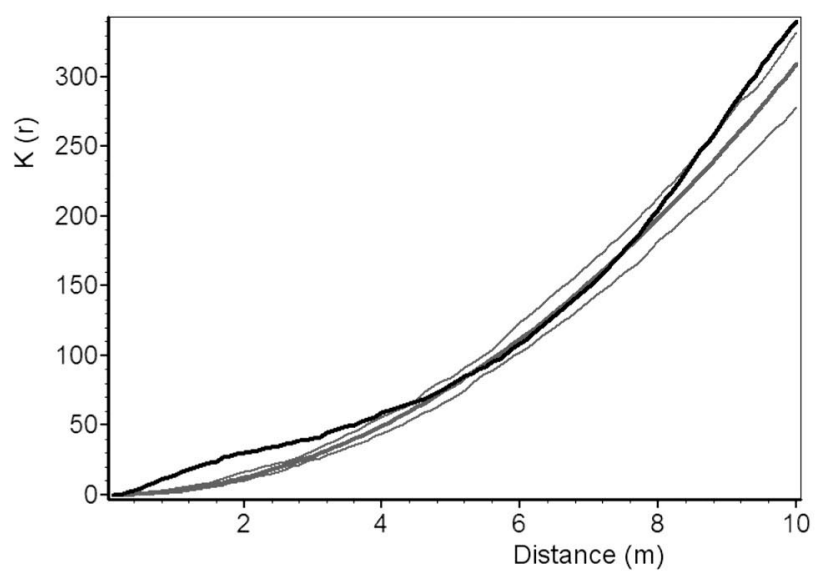

NATURAL REGENERATION 2010

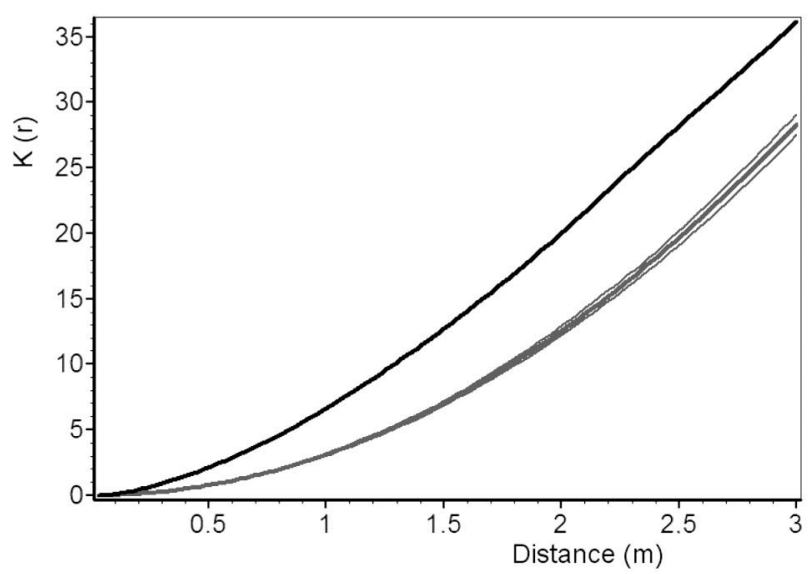

Fig. 3. Horizontal structure of beech stand on PRP 31 - U Hadí cesty F expressed by $K$-function 
Table 4. The development of index values of tree layer on PRPs to 2010 and 2040 after prediction of spontaneous development

\begin{tabular}{cccccc}
\hline PRP & Year & $\mathrm{A}(\mathrm{Pi})$ & $\mathrm{TM}_{\mathrm{d}}(\mathrm{Fi})$ & $\mathrm{TM}_{\mathrm{h}}(\mathrm{Fi})$ & $\mathrm{B}(\mathrm{J} \& \mathrm{Di})$ \\
\hline \multirow{3}{*}{31} & 1980 & 0.638 & 0.316 & 0.172 & 5.520 \\
& 2010 & 0.638 & 0.342 & 0.159 & 4.926 \\
& 2040 & 0.628 & 0.297 & 0.140 & 4.595 \\
\hline \multirow{2}{*}{29} & 1980 & 0.382 & 0.329 & 0.224 & 6.161 \\
& 2010 & 0.452 & 0.404 & 0.311 & 7.399 \\
27 & 2040 & 0.562 & 0.466 & 0.387 & 8.364 \\
\hline \multirow{2}{*}{27} & 0.467 & 0.256 & 0.145 & 6.645 \\
& 1980 & 0.508 & 0.259 & 0.224 & 6.943 \\
\end{tabular}

Explanatory notes: $A(P i)$ - vertical Arten-profile index, $T M_{d}(F i)$ - index of diameter differentiation, $T M_{h}(F i)$ index of height differentiation, $B(J \& D i)$ - total diversity index

lam, Pielou-Mountford and Clark-Evans) the distribution of individuals of the tree layer on this PRP is moderately regular. The moderately regular distribution of the tree layer individuals according to their distance (spacing) is also shown by Ripley's $K$-function while at a smaller spacing (less than $4 \mathrm{~m}$ ) the tree distribution on the plot is regular (Fig. 3). The horizontal structure of this stand has been moderately regular since the beginning of the observation and with the progressive dynamics of the stand the trend of regularity has been slightly increasing. Standing dead wood was from 1980 to 2010 distributed randomly and centroids of crown projection were regular. Table 3 also documents index values of the horizontal structure of natural regeneration recruits. According to all three calculated structural indices natural regeneration on this PRP is aggregated. The clumped distribution of natural regeneration recruits according to their distance is also shown by Ripley's $K$-function (Fig. 3).

Table 4 documents the values of structural indices (A - Arten-profil index, $\mathrm{TM}_{\mathrm{d}}$ - diameter differentiation index, $\mathrm{TM}_{\mathrm{h}}$ - height differentiation index and $\mathrm{B}$ - total diversity index) in the autochthonous European beech forest with interspersed sycamore maple on PRP 31 - U Hadí cesty F. It is a stand with high vertical diversity that has hardly changed during the stand development. Medium diameter and very low height differentiation of the stand will be decreasing from now on. Total diverstity of this stand was intermediate at the beginning of the observation and it has slightly decreased with progressive dynamics, which is caused by the absence of growing-up natural regeneration.

\section{PRP 29}

The number of individuals of the tree layer is 716 trees.ha $^{-1}$ (SDI 0.74) when the number of trees has increased more than twice since 1980. At present crown projection area reaches the value of 3.32 ha and crown closure 0.96 . The total per hectare num- ber of natural regeneration recruits is 13,320: beech accounts for almost $100 \%$ while the share of rowan and Norway spruce less than $1 \%$. Crown projection area and crown closure of natural regeneration are 0.51 and 0.25 ha, respectively. Rowan and spruce recruits are individually admixed.

According to all three calculated structural indices all individuals of the tree layer are distributed randomly on this PRP (Table 3, Fig. 2). The random distribution of individuals of the tree layer according to their distance (spacing) is also shown by Ripley's $K$-function at a tree spacing from $1 \mathrm{~m}$; at a smaller spacing the tree distribution on the plot is aggregated (Fig. 4). A more detailed analysis of the upper and lower storey indicates that codominant and dominant trees have a random distribution showing an inclination towards regularity $(\mathrm{HS}=0.486, \mathrm{PM}=1.088, \mathrm{CE}$ $=1.102$ ). On the other hand, the horizontal structure of shaded and intermediate trees is aggregated at a significance level of $95 \%$ ( $\mathrm{HS}=0.661, \mathrm{PM}=1.658$, $\mathrm{CE}=0.945) . K$-function also confirms the aggregated distribution of the lower storey (random distribution to a distance of $3 \mathrm{~m}$ ). In the last 15 years several tens of trees have passed from the growth stage of younggrowth stand to the small pole stage, which has accentuated the random distribution of trees to a larger extent. Random distribution is expected in several subsequent years. On the contrary, with accelerated disintegration of the upper storey several growing-up groups would create an aggregated structure. Both, the horizontal structure of crown projection centroids and snags is random. Spatial distribution of natural regeneration on this PRP is aggregated according to selected structural indices (Table 3), and also according to the Ripley's $K$-function (Fig. 4).

PRP 29 is characterized by medium vertical diversity that is slowly increasing with ongoing disintegration of the stand and with the onset of a new forest generation. Diameter differentiation index documents a stand of medium and/or low differentiation in 2010. Based on the $\mathrm{TM}_{\mathrm{h}}$, this stand can be considered as intermediately differentiated. It is so, 


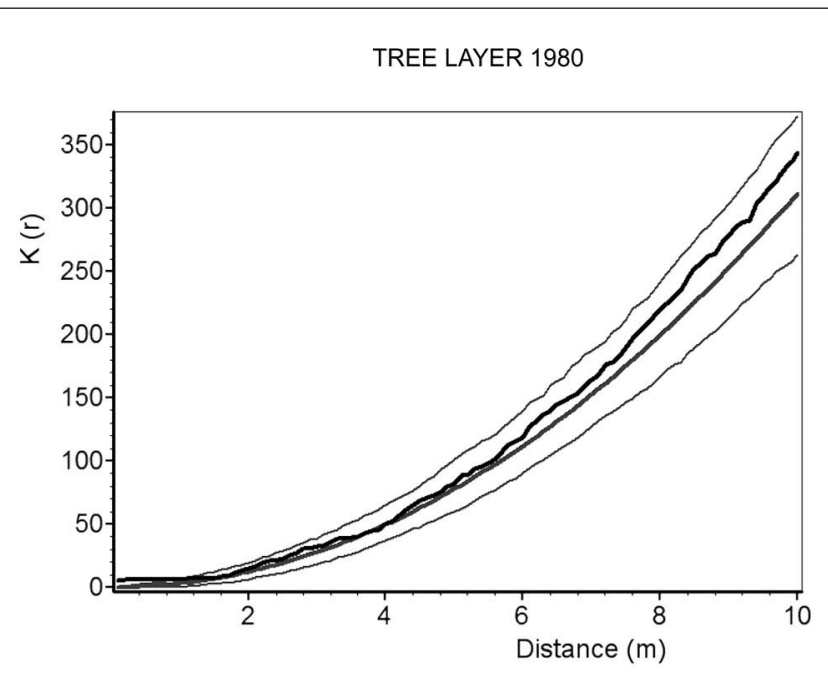

TREE LAYER 2040

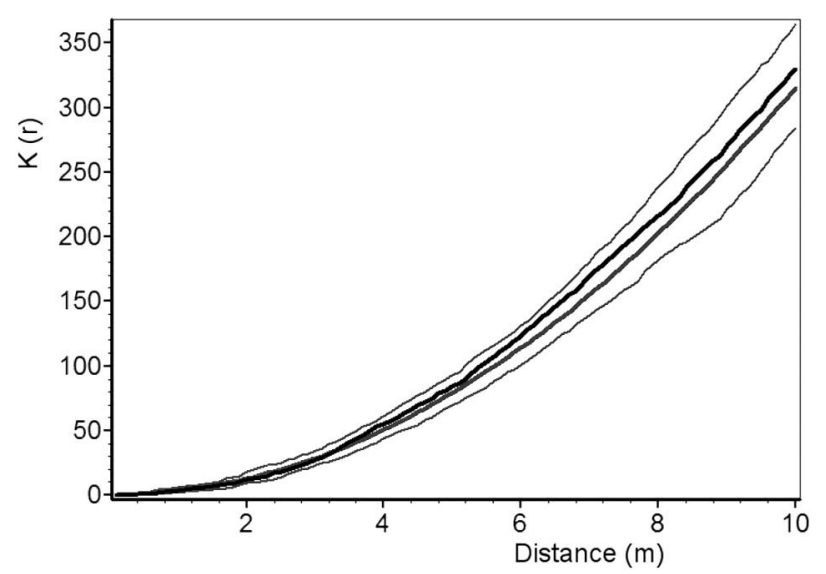

TREE LAYER 2010

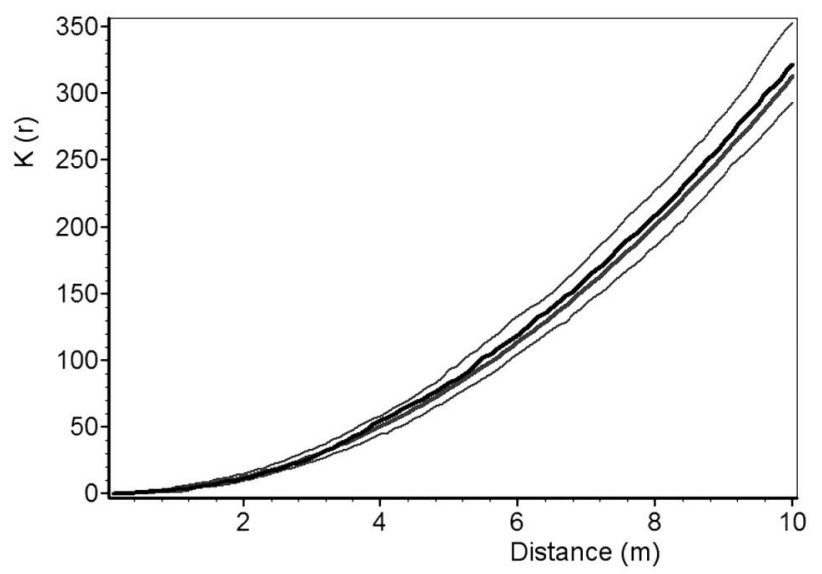

NATURAL REGENERATION 2010

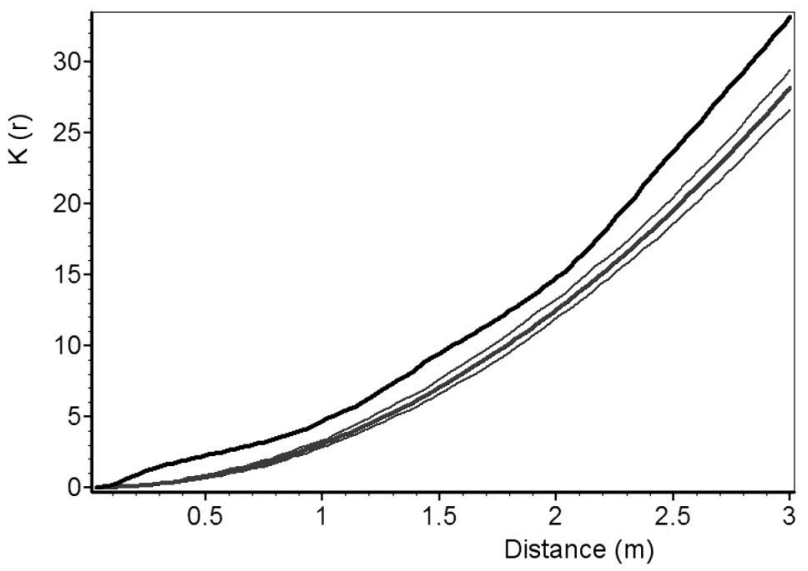

Fig. 4. Horizontal structure of beech stand on PRP 29 - U Bukového pralesa B expressed by K-function

because the height of the overwhelming majority of trees distinctly deviates from the mean height of the stand (11.83 $\mathrm{m} \pm 6.14$ S.D.), only a few trees have a height around this mean. Both values of structural differentiation show a steady increase (Table 4.). Total diversity of this forest was intermediate at the beginning of the observation while it is increasing with ongoing disintegration of the stand. With the gradual growing up of further trees to the upper storey a change in the stand structure from uneven structure to relatively rich structure is to be expected.

\section{PRP 27}

The total number of individuals of the tree layer per hectare was 768 (SDI 0.79). At present the value of crown projection area is 2.26 ha and that of crown closure is 0.90 . The total per-hectare number of natural regeneration recruits is 47,960 while beech accounts for $95 \%$, rowan for $4 \%$ and Norway spruce for $1 \%$. Crown projection area of natural regeneration is 0.05 and crown closure of natural regeneration is 0.06 ha.
Spatial pattern of the tree layer is aggregated (Fig. 2 , Table 3), which is also truth for the natural regeneration on this PRP. The distribution of individuals of the tree layer and natural regeneration indicated by Ripley's K-function is shown on Fig. 5; in the spacing range of 5-9 $\mathrm{m}$ the tree distribution across the plot is random, at lower and higher spacing aggregated. Distribution of natural regeneration is aggregated by $K$-function. The horizontal structure of crown projection centroids was random to regular and had much more higher values towards the regularity than tree layer. Standing dead wood on PRP 27 showed again random spatial pattern. Simulations of spontaneous development of the horizontal structure do not reveal any pronounced changes in the future.

Table 4 documents the values of structural indices in an autochthonous beech stand with rowan admixture and interspersed spruce on PRP 27. It is a stand of medium vertical diversity that will increase only slightly within 60 years of development with oscillations. Diameter and height differentiation of the stand is relatively low and it will gradually increase in the years to come. These both values of TM index 


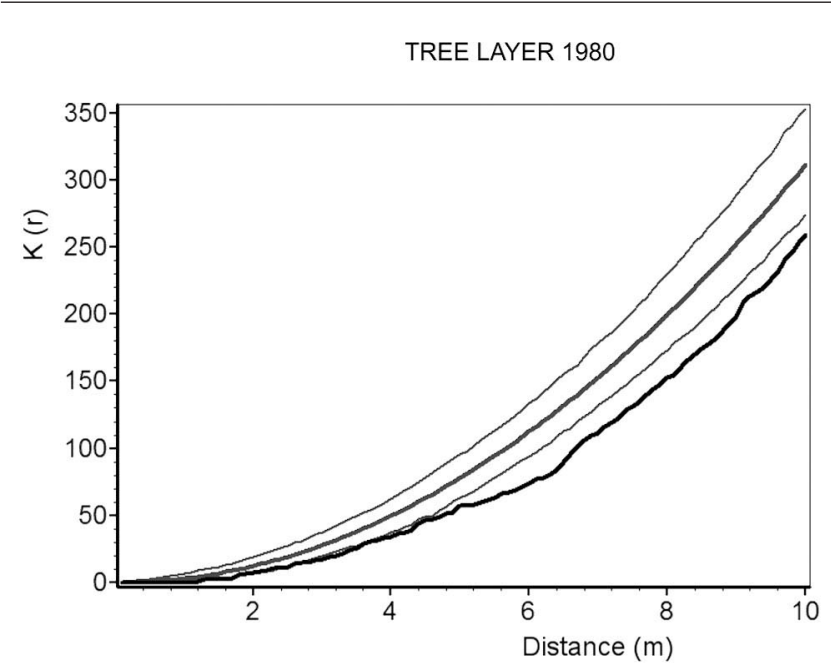

TREE LAYER 2040

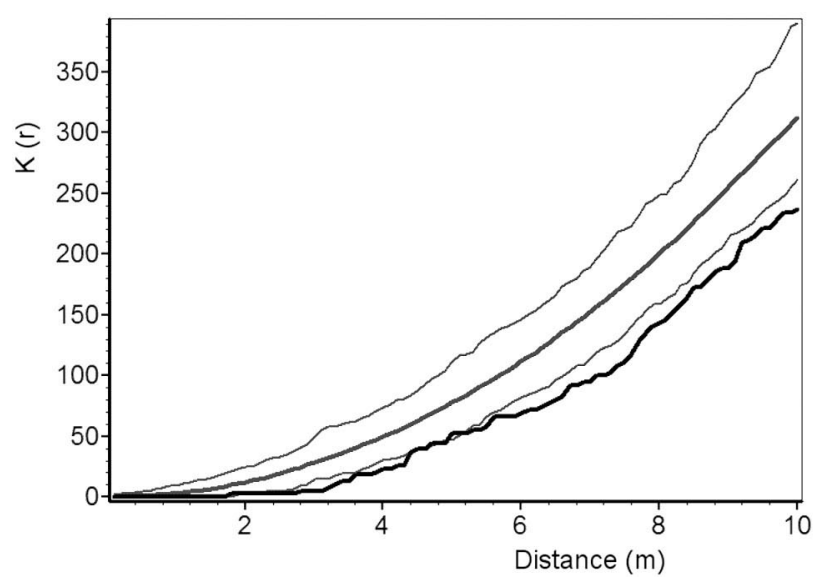

Fig. 5. Horizontal structure of the beech stand on PRP 27 - U Bukového pralesa A expressed by K-function

are the lowest determined values on all PRP. Total diversity of this stand reached mean values at the beginning of the observation (irregular structure) while it has slowly been increasing with ongoing disintegration of the stand and subsequent growing-up of natural regeneration.

Results of the PCA analysis are presented in the form of the ordination diagram on Fig. 6. The first ordination axis explained $53 \%$, the first two axes together $78 \%$ and the first four axes together $98 \%$ variability of data. The first axis $\mathrm{x}$ represented altitude and slope, together with live tree density, tree height and $\mathrm{DBH}_{1.3}$. Second axis y represented the course of time (since 1980 till 2040) and average age of stand with canopy (crown projection area and crown closure). Number of trees and altitude were positively correlated $(\mathrm{P}<0.05)$ to one another with aggregation indices (or negatively with Clark-Evans index). Average height of trees was positively correlated with $\mathrm{DBH}_{1.3}$ and Arten profile index, while these parameters were negatively correlated with Total diversity index. Indicators of canopy and partially height with diameter differentiation are increasing in the course of time, while average age of living trees in the stand
TREE LAYER 2010

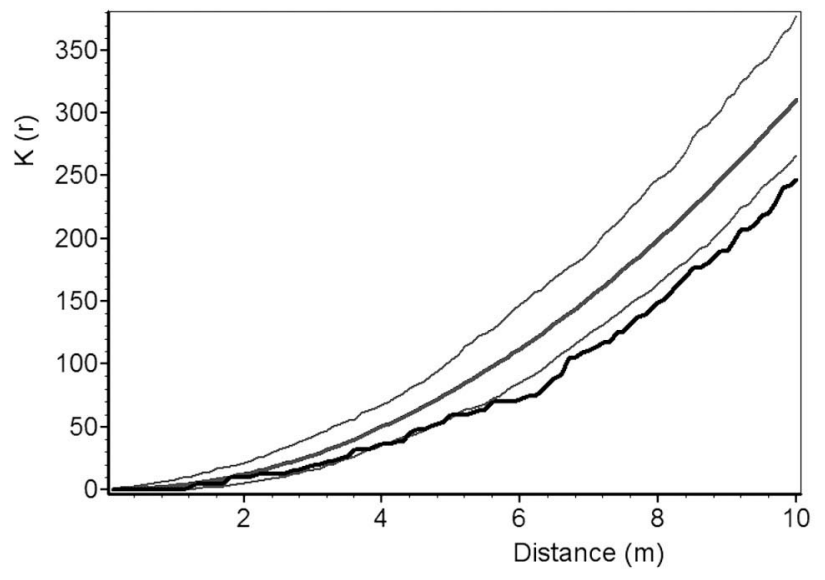

NATURAL REGENERATION 2010

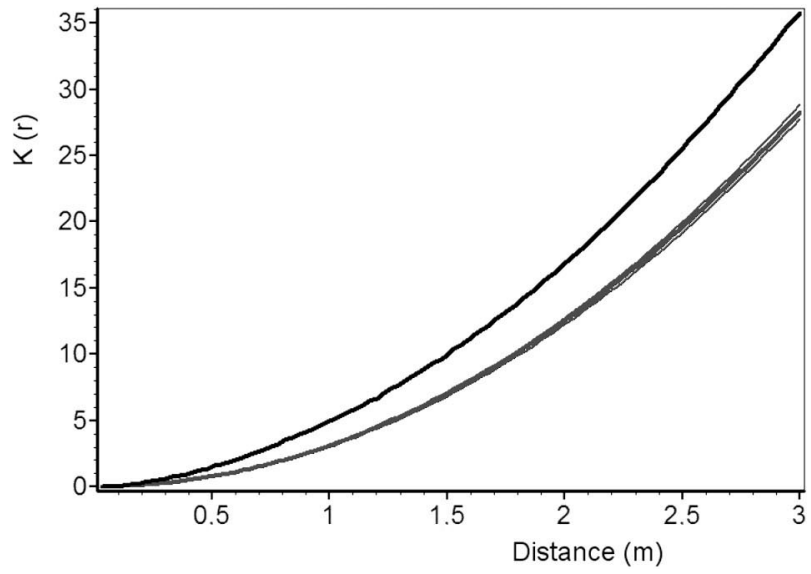

is decreasing in the time, namely due to new recruits. The dynamics of parameters in the course of 60 years was remarkable especially for PRP 29 as marks of each record are relatively distant from one another (move from the break up to growing up stage), whereas marks for PRP 31 representing the optimum stage were relatively close together in the diagram.

\section{Discussion}

The horizontal distribution of spruce trees in a montane zone, particularly in the timberline area, was studied by many authors (e.g. Holeksa et al. 2007; Pittner and Saniga 2008), but to the spatial structure of mountain beech forests has been paid less attention (cf. Vacek and Hejcman 2012). On all investigated plots all used indices (Hopkins-Skellam index, Pielou-Mountford index, Clark-Evans) were in the interval of values indicating aggregated through random to regular distribution of trees. Tree distribution on PRP 31 in biostatic developmental stage showed a tendency of regular spatial pattern (from $3 \mathrm{~m}$ ). Regular spacing is often the result of 


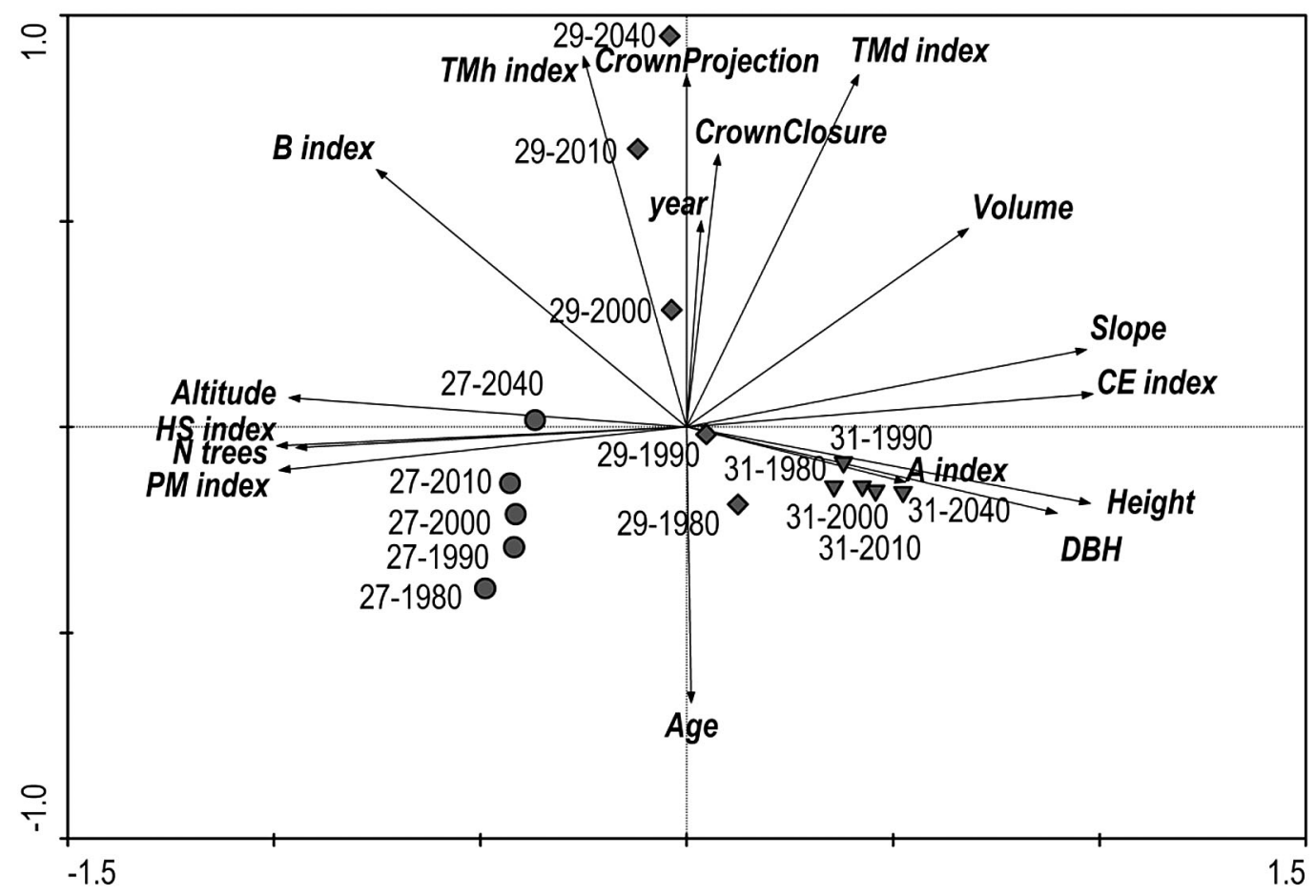

Fig. 6. Ordination diagram showing results of PCA analysis of relationships among living trees characteristics, stand parameters, structural indexes and time

competition of neighbouring trees. Regularity in distribution of the upper storey trees was also observed in beech forests in Slovenia (Rugani et al. 2013). Random distribution of all individuals of the tree layer prevails on PRP 29 situated at a lower altitude, which is result of disintegration of the overstorey. Spatial analyses documented that the upper storey is distributed randomly showing an inclination towards regularity but trees in the lower storeys have a clumped distribution. This spatial pattern was also observed in other natural beech forests (von Oheimb et al. 2005; Commarmot et al. 2005). An inclination towards aggregation in the lower storey is a result of the successful aggradation of natural regeneration in canopy gaps (Zeibig et al. 2005). Shift from significantly aggregated distribution of new recruits through random to regular in large sized trees $\left(\mathrm{DBH}_{1.3}>32.5 \mathrm{~cm}\right)$ was also confirmed in near-natural beech forests in France (Wijdeven 2004). The aggregated spatial pattern of tree layer individuals on PRP 27 at the altitude $1030 \mathrm{~m}$ a.s.l. is the effect of former intensive cattle grazing (Vera 2000) and summit phenomenon with harsh climate conditions. Trees are distinctly aggregated to a distance of $4 \mathrm{~m}$ and subsequently from $8 \mathrm{~m}$. In these extreme conditions trees grow in biogroups; natural regeneration of beech is also more successful in the shelter of larger trees. This trend of deviation from random distribution was observed also in the ecotone of the timberline that is accentuated there by vegetative propagation as an adaptation to extreme growth conditions (Doležal and Šruotek 2002; Vacek et al. 2010b).

Similarly like in other studies on Fagus sylvatica natural regeneration (Nagel et al. 2006; Vacek et al. 2010b), the horizontal structure of regeneration was found to be distinctly aggregated. Aggregated spatial pattern of natural regeneration recruits on all PRP was confirmed also by Ripley's $K$-function indicating clear preference of young beech individuals for specific microsite conditions. Spatial patters of the crown projection centroids were from random to regular. As in our case Schröter (2012) shows that the crowns of beech were more regularly distributed than their trunks (most of the PRP 27), which is caused by phototropism and crown plasticity of beech growth allowing efficient use of space. Snags had during the whole observation period strictly random distribution regardless of altitude. This spatial pattern was founded also in Sarrahn natural beech forest in Germany (von Oheimb et al. 2007).

The value of Arten-profil index on the studied localities in 2010 ranged from 0.45 to 0.64 , which indicates stands of medium to high vertical diversity. The highest value of the Füldner's index of diameter and height differentiation was reached on PRP 29. The lowest height differentiation (0.16) was found on PRP 31. Similar values of the Arten-profil index (0.44 and 0.45) were determined in 90-years-old beech stands in Slovakia (Cigánka PRP and Zlatá Idka PRP) that were left to spontaneous development (Štefančík 2013). Intermediate structure differentiation 
was also observed on all PRPs according to the Füldner's index of diameter and height differentiation (0.40 and 0.43). PRP 27 under the strong influence of extreme climatic conditions shows rather limited growth of trees (smallest tree dimensions among the studied plots) and relatively low differentiation of diameter structure. The complexity stand diversity index of natural beech fragments in the eastern Krkonoše Mts. indicated that these are stands with mostly irregular structure. Rather regular structure was found out on PRP 31, representing late biostatic developmental phase.

The resultant value of reliability of future development simulation depends on the growth simulator error expressing the deviation of a subsequently modelled stand from its actual condition (Pretzsch 2001). The author of the growth simulator of forest biodynamics SIBYLA (Fabrika 2005) stated that at a $95 \%$ statistical significance level for the prediction interval of 50 years the mean error of per-hectare standing volume was $\pm 5 \%$ for an unmixed even-aged stand generated from tree data including the coordinates while it was $\pm 15 \%$ (error of mean $\mathrm{DBH} \pm 8 \%$, mean height $\pm 6 \%$ ) for an unmixed uneven-aged stand generated from stand data. In our case, considering the complexity of input data, prediction interval of 30 years and age structure of the forest stand composed mostly of one tree species, the maximum magnitude of mean error is estimated to be $\pm 8 \%$. The comparison of the actual condition of the forest on PRP measured after 10 years and development simulations based on 1980 input data did not reveal any larger differences. These differences were considerably minimized after subsequent prediction by adding new trees reaching the registration limit. Generally, the most significant deviation was observed on PRP 27 because the stand growth on this plot is distinctly influenced by extreme conditions of the summit phenomenon.

No distinct changes have occurred in the horizontal structure on all PRP since 1980 and in the subsequent prediction of stand development by the SIBYLA simulator till 2040. Similar results were confirmed by Korpel' (1995), who concluded that extensive disturbances in natural beech stands are very scarce. The values of indices of height variability, structure differentiation and total stand variability on PRP 27 and 29 showed a positive increase during the period of observation. These changes in structural characteristics can be expected from now on as a result of gap dynamics and gradual growing-up of natural regeneration recruits above the registration limit. A pronounced increase in the values of these indices was recorded on PRP 29, e.g. the assumed value of total stand variability in 2040 amounting to 8.4 exceeded the boundary from the originally almost regular stand structure to relatively complex forest structure. In PRP 31, where the simulator predicts the lowest mortality, all indices show a downward tendency. Vertical diversity is the only exception with rather constant values during the observation period.

Our research has revealed the relatively high quality of prediction of the used growth model. Research of Špulák and Souček (2010) also showed only moderate differences in evaluated stand indices between reality and models. However, in fact it is to take into account that the dynamics of beech forests may be influenced by unforeseeable anomalous disturbances of high intensity (Mountford 2002; Closset-Kopp et al. 2006). On the other hand, beech forests in the montane zone are less exposed to these events compared with lowland beech forests in NW Europe with generally windier climate (Christensen et al. 2005).

With very pronounced microsite differences that are typical of forest stands in the area of the distinct summit phenomenon or near the timberline (cf. Vacek and Hejcman 2012) also mature stands tend to maintain here the aggregated structure that is typical only for juvenile stages of beech forests in more favourable sites (herb-rich beech forests). The results show, thus spatial pattern of tree layer dependent on the altitude, but also on the number of trees that is closely associated with the development stage.

\section{Acknowledgement}

This study was supported by the Internal Grant Agency (IGA no. B0114 ), Faculty of Forestry and Wood Sciences, Czech University of Life Sciences Prague.

\section{References}

Barrera M.D., Frangi J.L., Richter L.L., Perdomo M.H., Pinedo L.B. 2000. Structural and functional changes in Nothofagus pumilio forests along an altitudinal gradient in Tierra del Fuego, Argentina. Journal of Vegetation Science 11: 179-188.

Christensen M., Hahn K., Mountford E.P., Odor P., Standovar T., Rozenbergar D., Diaci J., Wijdeven S., Meyer P., Winter S., Vrska T. 2005. Dead wood in European beech (Fagus sylvatica) forest reserves. Forest Ecology and Management 210: 267-282.

Clark P.J., Evans F.C. 1954. Distance to nearest neighbor as a measure of spatial relationships in populations. Ecology 35: 445-453.

Closset-Kopp D., Schnitzler A., Aran D. 2006. Dynamics in natural mixed-beech forest of the Upper Vosges. Biodiversity and Conservation 15: 1063-1093.

Commarmot B., Bachofen H., Bundziak Y., Bürgi A., Ramp B., Shparyk Y., Sukhariuk D., Viter R., Zingg A. 2005. Structures of virgin and managed 
beech forests in Uholka (Ukraine) and Sihlwald (Switzerland): a comparative study. Forest Snow and Landscape Research 79: 45-56.

Crookston N.L., Stage A.R. 1999. Percent canopy cover and stand structure statistics from the Forest Vegetation Simulator. US Department of Agriculture, Forest Service, Rocky Mountain Research Station

Doležal J., Šrůtek M. 2002. Altitudinal changes in composition and structure of mountain-temperate vegetation: a case study from the Western Carpathians. Plant Ecology 158: 201-221.

Ellenberg H. 1996. Vegetation Mitteleuropas mit den Alpen. 5.Aufl. Ulmer, Stuttgart.

Fabrika M. 2005. Simulátor biodynamiky lesa SIBYLA, koncepcia, konštrukcia a programové riešenie. Technická univerzita vo Zvolene.

Ferris-Kaan R., Peace A.J., Humphrey J.W. 1998. Assessing structural diversity in managed forests. In: Assessment of Biodiversity for Improved Forest Planning. European Forest Institute Proceedings 18. Bachmann P. (ed.). Kluwer Academic Publishers, p. 331-342.

Füldner K. 1995. Strukturbeschreibung in Mischbeständen. Forstarchiv 66: 235-606.

Geyer C.J. 1999. Likelihood Inference for Spatial Point Processes. Chapter 3 In: Geometry: Likelihood and Computation. Barndorff-Nielsen O.E., Kendall W.S., Van Lieshout M.N.M. (eds.). Stochastic Chapman and Hall/CRC, Monographs on Statistics and Applied Probability 80: 79-140.

Girardin C.A.J., Farfan-Rios W., Garcia K., Feeley K.J., Jørgensen P.M., Murakami A.A., Perez L.C., Seidel R., Paniagua N., Fuentes Claros A.F., Maldonado C., Silman M., Salinas N., Reynel C., Neill D.A., Serrano M., Caballero C.J., de los Angeles La Torre Cuadros M., Macia M.J., Killeen T.J., Malhi Y. 2014. Spatial patterns of above-ground structure, biomass and composition in a network of six Andean elevation transects. Plant Ecolology and Diversity 7: 161-171.

Holdridge L.R. 1967. Life zone ecology. Tropical Science Center. San Jose, Costa Rica.

Holeksa J., Saniga M., Szwagrzyk J., Dziedzic T., Ferenc S., Wodka M. 2007. Altitudinal variability of stand structure and regeneration in the subalpine spruce forests of the Polana biosphere reserve, Central Slovakia. European Journal of Forest Research 126: 303-313.

Hopkins B., Skellam J.G. 1954. A new method for determining the type of distribution of plant individuals. Annals of Botany 18: 213-227.

Jaehne S.C., Dohrenbusch A. 1997. Ein Verfahren zur Beurteilung der Bestandesdiversität. Forstwissenschaftliches Centralblatt 116: 333-345.

Jeník J. 1998. Biodiversity of the Hercynian mountains of Central Europe. Pirineos 151/152: 83-99.
Kooijman A.M., Emmer I.M., Fanta J., Sevink J. 2000. Natural regeneration potential of the degraded Krkonoše forests. Land Degradation and Development 11: 459-473.

Korpel Š. 1995. Die Urwälder der Westkarpaten. Stuttgart, Jena, New York, Gustav Fischer Verlag.

Le Tacon F. 1981. Caractérisation edaphique. In: Le hêtre. Teissier du Cros E., Le Tacon F., Nepveu G., Pardé J., Perrin R., Timbal J. (eds.). INRA, Paris, pp. 77-84.

McElhinny C., Gibbons P., Brack C., Bauhus J. 2005. Forest and woodland stand structural complexity: its definition and measurement. Forest Ecology and Management 218: 1-24.

Ministry of Agriculture of the Czech Republic 2013. Report on the state of forests and forestry in the Czech Republic by 2013.

Motta R., Morales M., Nola P. 2006. Human land-use, forest dynamics and tree growth at the treeline in the Western Italian Alps. Annals of Forest Science 63: 739-747.

Mountford E.P. 2002. Fallen dead wood levels in the near-natural beech forest at La Tillaie reserve, Fontainebleau, France. Forestry 75: 203-208.

Mountford M.D. 1961. On E. C. Pielou's index of non-randomness. Journal of Ecology 49: 271-275.

Nagel T.A., Svoboda M., Diaci, J. 2006. Regeneration patterns after intermediate wind disturbance in an old-growth Fagus-Abies forest in southeastern Slovenia. Forest Ecology and Management 226: 268-278.

Neuhäuslová Z., Blažková D., Grulich V., Husová M., Chytrý M., Jeník J., Jirásek J., Kolbek J., Kropáč Z., Ložek V., Moravec J., Prach K., Rybníček K., Rybníčková E., Sádlo J. 1998. Mapa potenciální přirozené vegetace České republiky. Textová část. (Map of the Potential Natural Vegetation of the Czech Republic. Explanatory text.). Academia, Praha.

Neumann M., Starlinger F. 2001. The significance of different indices for stand structure and diversity in forests. Forest Ecology and Management 145: 91-106.

Otto H.J. 1994. Waldökologie. Stuttgart, Ulmer.

Pittner J., Saniga M. 2008. A change in structural diversity and regeneration processes of the spruce virgin forest in Nefcerka NNR (TANAP) in relation to altitude. Journal of Forest Science 54: 545-553.

Pretzsch H. 1992. Konzeption und Konstruktion von Wuchsmodellen für Rein- und Mischbestände. Forstliche Forschungsberichte, München.

Pretzsch H. 2001. Modellierung des Waldwachstums. Parey Buchverlag, Berlin.

Pretzsch H. 2009. Forest Dynamics, Growth and Yield. Springer.

Rademacher C., Neuert C., Grundmann V., Wissel C., Grimm V. 2001. Was charakterisiert Buchenur- 
wälder? Untersuchungen der Altersstruktur des Kronendachs und der raümlichen Verteilung der Baumriesen in einem Modellwald mit Hilfe des Simulationsmodells BEFORE. Forstwissenschaftliches Centralblatt 120: 288-302.

Ripley B. D. 1977. Modelling Spatial Patterns. Journal of the Royal Statistical Society. Series B 39: 2: $172-212$.

Rozas V. 2006. Structural heterogeneity and tree spatial patterns in old-growth deciduous lowland forest in Cantabria, northern Spain. Plant Ecology 185: 57-72.

Rugani T., Diaci J., Hladnik D. 2013. Gap Dynamics and Structure of Two Old-Growth Beech Forest Remnants in Slovenia. PloS one 8: e52641.

Schröter M., Härdtle W., von Oheimb G. 2012. Crown plasticity and neighborhood interactions of European beech (Fagus sylvatica L.) in an old-growth forest. European Journal of Forest Research 131: 787-798.

Šmelko Š. 2007. Dendrometria. $2^{\text {nd }}$ release. Zvolen. TU Zvolen.

Špulák O., Souček J. 2010. The Sibyla model and development of beech forests affected by air pollution. Central European Journal of Biology 5: 371-383.

Štefančík I. 2013. Effect of delayed tending on development of beech (Fagus sylvatica L.) pole stage stand. Folia Oecologica 40: 272-281.

ter Braak C.J.F., Šmilauer P. 2002. CANOCO Reference Manual and CanoDraw for Windows User's Guide: Software for Canonical Community Ordination (version 4.5). Ithaca, NY, USA (www.canoco.com): Microcomputer Power.

Vacek S., Nosková I., Bílek L., Vacek Z., Schwarz O. 2010a. Regeneration of forest stands on permanent research plots in the Krkonoše Mts. Journal of Forest Science 56: 11: 541-554.

Vacek S., Vacek Z., Schwarz O., Raj A., Bilek L., Noskova I., Balcar Z., Zahradnik D., Balas M., Bed- narik J., Mikesa M., Minx T., Matejka K. 2010b. Struktura a vývoj lesních porostů na výzkumných plochách v národních parcích Krkonoš. Kostelec nad Černými lesy: Lesnická práce.

Vacek S., Hejcman M. 2012. Natural layering, foliation, fertility and plant species composition of a Fagus sylvatica stand above the alpine timberline in the Giant (Krkonoše) Mts., Czech Republic. European Journal of Forest Research 131: 799-810.

Vera F.W.M. 2000. Grazing ecology and forest history. CABI Publishing, Oxon.

von Oheimb G., Westphal C., Härdtle, W. 2007. Diversity and spatio-temporal dynamics of dead wood in a temperate near-natural beech forest (Fagus sylvatica). European Journal of Forest Research 126: 359-370.

von Oheimb G., Westphal C., Tempel H., Härdtle W. 2005. Structural pattern of a near-natural beech forest (Fagus sylvatica) (Serrahn, north-east Germany). Forest Ecology and Management 212: 253-263.

Weber J. 1999. Beschreibung der Diversität von Bestandesstrukturen mit Hilfe von Teilkollektiven. Tagung des Deutschen Vereins Forstlicher Forschungsanstalten. Sektion Forstliche Biometrie und der AG Okologie der Internationalen $\mathrm{Bi}$ ometrischen Gesellschaft in Freiburg, pp. 25-37.

Wijdeven S.M.J. 2004. Stand dynamics in Fontainebleau. Dynamics in beech forest structure and composition over 17 years in La Tillaie forest reserve, Fontainebleua, France. Green World Research, Alterra.

Wolf A. 2005. Fifty year record of change in tree spatial patterns within a mixed deciduous forest. Forest Ecology and Management 215: 212-223.

Zeibig A., Diaci J., Wagner S. 2005. Gap disturbance patterns of a Fagus sylvatica virgin forest remnant in the mountain vegetation belt of Slovenia. Forest Snow and Landscape Research 79: 69-80. 